\title{
テレビジョン自動同期結合装置
}

$\begin{array}{lllll} & \text { 藤 } & \text { 村 } & \text { 安 } & \text { 志 } \\ \text { NHK 技術研究所 } & \text { 三 } & \text { 井 } & \text { 信 } & \text { 雄 } \\ & \text { 上 } & \text { 原 } & \text { 隆 } & \text { 司 }\end{array}$

$\mathrm{TV}$ 局間の同期結合方式は, 從来, $\mathrm{RCA}$ で開発した Gen-Lock 方式，NHK ウォキールッキー，BBC など で試用された水平同期の基準となる信号伝送による結合 方式などがある.しかしこれらの方式には次の諸点につ いて一長一短がある.（1）Ｇen-Lock 方式：同期結合 方式としては上手な設計といえるが，外来信号に混入す る雑音（特にパルス性雑音）によって水平ロック離れ， 垂直流れを生ずる，また雑音によるじよう乱拉よび入力 他局同期の断によって自局の同期が乱れたり, 水平同期 周波数がかなりはずれた值に偏移する.多元同期ができ ない（2）水平同期基準伝送方式：他局に水平同期の 基準を送っているので，雑音などの外来の影響で自局同 期が犯されることがない. 多元同期が可能である. しか 乙同期結合を維持するためには他局からくる映像回線と， 自局から他局へ送る基準信号回線を保守しなければなら ない。

本文で述べる自動同期結合装置は，この二つの方式の 長所を採り入れるよう考光て設計して山る.

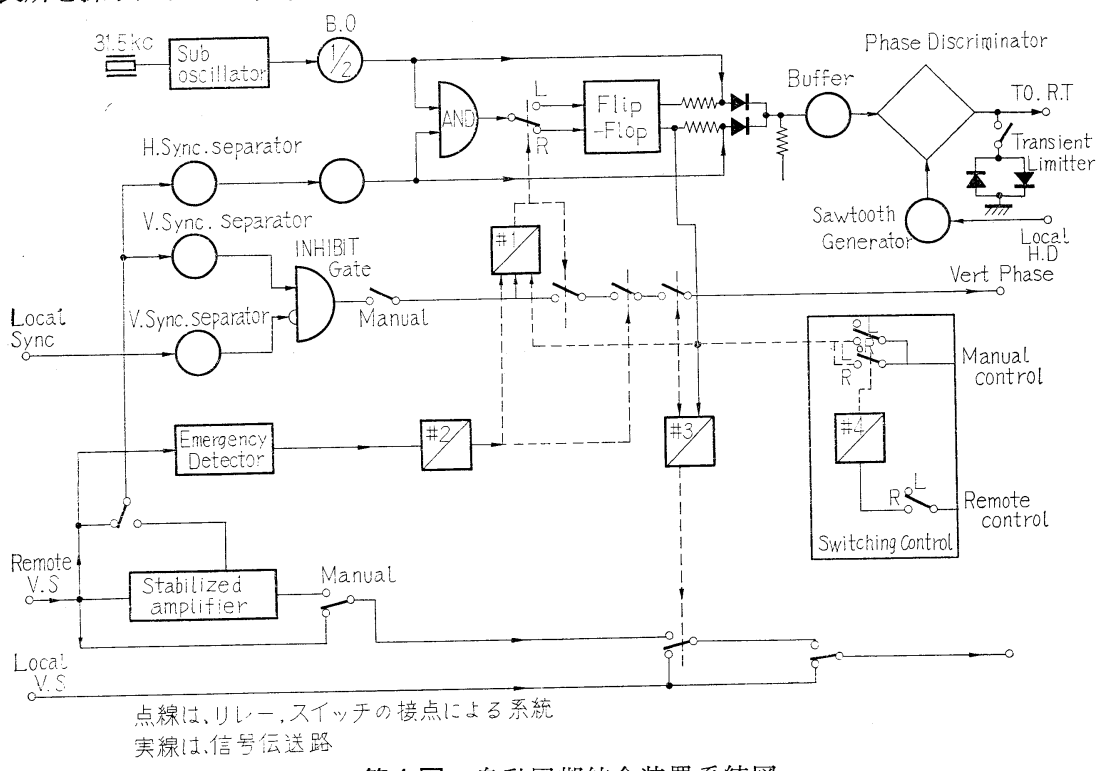

第 1 図 自動同期結合装置系統図
動 作 原 理

この自動同期結合装置の動作基本原理を第 1 図に示す。 他局の V.S. 信号は安定化增幅器で分離され S 信号とし て入力に加わる(直接 V.S. $1.4 \mathrm{Vp}-\mathrm{p}$ で加えてもよい). この信号は正規の信号レベルがあるかないかを障害検出 回路で確認させる.十分放送できると評価された場合，

（後述するように映像レベルの大きさで比較される）直 ちに垂直同期位相差は検 出し, 自局同期信号発生器の ５25 カウンターを補正パルスにより誤動作させて一致 させる.この動作が完了すると水平同期位相差はリアク タンス管を用いた AFC 回路により結合するＡFCの 規準周波数は他局同期が正規にきていない場合には, 自 動同期結合装置に自蔵している $31.5 \mathrm{kc}$ 水晶発振周波数 であり, AFC はこの周波数に結合している.

これらの動作は安定に, 切換操作の不便なく自動的に 同期結合を行ならょう考慮してある.しかもこの同期結 合は，番組構成上からは一連の連続画面として一般市販 受像器に障害をほとんど 与えない。をた局間回線, 中継回線の事故が生じた 場合には, 障害検出回路 が動作して直ちに自動的 に自局同期执よび自局番 組に切替わる。

\section{同期切替結合に伴 う諸現象}

\section{1. 垂直同期の結合} 垂直同期の位相は RC-

$\mathrm{A}$ ，Gen-Lock 方式と同 様, 補正パルスによって 自局同期信号発生器を誤 動作させて行なう・この 方式では調相期間中，自 局同期の走查線数が変化

“Television Automatic Sync. Lock Equipment” by Yasushi Fujimura, Nobuo Mii\& Takashi Uehara. 


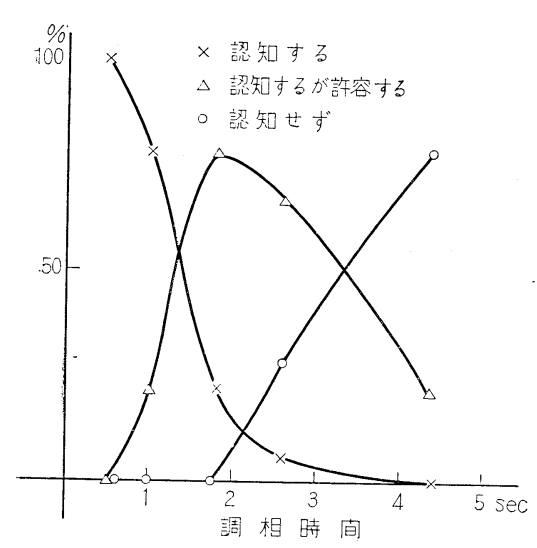

第 2 図垂直調相時間の認知限界

するので，場合によっては聴視者が異状を認知する．第 2 図はこの認知限界を測定したもので，垂直位相の最大 偏差点（ほとんぞ $1 \mathrm{~V}$ ずれた場合）より位相一致時間を 5 秒とすれば（垂直周波数偏差 $0.33 \%$ )，この周波数逓 降回路の弓ち動作はほとんぞわからない，ただ走査数が 偶数となると，飛越走查が行なわれないので絵がらによ ってはわかる程度である。

\section{2. 水平同期の結合}

水平同期の結合を $\mathrm{AFC}$ 回路のついた受像機で画面に 同期乱机を与えることなく行ならにはかなりの考虑を必 要とする.すなわち一般市販の受像機に挍いてインディ シャルな入力位相の変化に対して, その水平 $\mathrm{AFC}$ 回路 の過渡応答は定常值に達するまでかなりの時間を必要と し $10 \mathrm{~ms}$ 程度にもなる.

AFC の過渡応答を調べるため, 回路動作を自動制御 で用いられるブロック線図で表わすと第 3 図のように示 される，このブロック線図はある定常值よりの時間的変 化を示して和り，位相差の定常值 $\phi_{D}$ は他局同期周波数 を $\omega_{1}$ 自局固有の発振周波数を $\omega_{0}$ とすれば

$$
\phi_{D}=\frac{\omega_{1}-\omega_{0}}{K}
$$

但し $K=K_{1} \cdot K_{2}$ で与兄られている. $K$ は AFC の利 得と呼ばれるもので

$$
K=\frac{\Delta \omega_{0}}{\Delta \phi_{D}}
$$

で示され dimension は $1 / \mathrm{sec}$ である.この AFC は実 際注 $\mathrm{H}$ パルスごとにサンプルされる時間系列不連続 な制御系であるが, 過渡応答の周期に比して, サンプル 周期が短かいので連続関数として近似ができる.注 11 よ って入力がインディシャル変化として, 出力位相 $\phi_{2}(s)$ を求めると,

$$
\phi_{2}(s)=\frac{K a}{\left(s^{2}+s a+K a\right)} \cdot \frac{\phi_{1}}{s}
$$

$$
\text { 但し } f(s)=\frac{a}{s+a} \text { として }
$$

または

$$
\begin{array}{r}
\phi_{2}(s)=\frac{K \frac{a}{b}(s+b)}{s^{2}+\left(a+K \frac{a}{b}\right) s+K a} \cdot \frac{\phi_{1}}{s} \\
\text { 但し } f(s)=\frac{a}{b} \frac{s+b}{s+a} \text { として }
\end{array}
$$

のように $f(s)$ の低域フイルタの型で二と打りにあら わされる。

これを逆ラプラス変換して $\left|\frac{\phi_{2}}{\phi_{1}}\right|(t)$ を求めると, 式は

$$
\left|\frac{\phi_{2}}{\phi_{1}}\right|(t)=1+\frac{1}{\sqrt{1-\frac{a}{4 K}}} \varepsilon \sin \left(\sqrt{K a-\frac{a^{2}}{4}} t+\theta\right)
$$

$$
\text { 但し } \theta=\sin ^{-1}\left(-\sqrt{1-\frac{a}{4 K}}\right)
$$

(4) 式は

$$
\begin{gathered}
\left|\frac{\phi_{2}}{\phi_{1}}\right|(t)=1+\frac{\sqrt{1-\frac{a}{b}}}{\sqrt{1-\frac{a}{4 K}\left(1+\frac{K}{b}\right)^{2}}} \varepsilon^{-\frac{a}{2}\left(1+\frac{K}{b}\right) t} \\
\sin \left(\sqrt{K a-\frac{a^{2}}{4}\left(1+b^{2}\right) t+\theta}\right) \\
\text { 但し } \quad \theta=\sin ^{-1}\left(-\sqrt{\frac{1-\frac{a}{4 K}(1+b)^{2}}{1-\frac{a}{b}}}\right)
\end{gathered}
$$

の型で表わされる.

第 4 図は理論的に求めたものと, 実測值との対比を示 した一例で, $3 \mathrm{~ms}$ の付近でオーバシュートを生じ定常 值になるまで $10 \mathrm{~ms}$ るかかることを示している.

この結果からもわかるように, 過渡状態が長く, しか も振動形となる場合も, 利得 $K$ とフィルタの定数によ って考党られるので，視覚に与える影響は無視できな

注 1)この証明は筆者によって, $z$ 変換を用いて理論的にも実験的にも 明らかにされている.
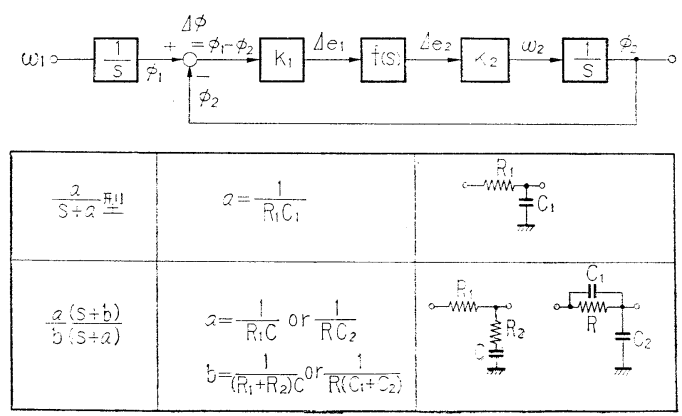

第3図 $\mathrm{AFC}$ ブロック線図 
い. 実験によると位相変化に対するラスタ一上の認知限 界はかなり綮しく， $\phi_{D}$ が $0.5 \%$ 以上あれば変化を認め られる.ゆ光に水平同期の切替えは他局と自局の同期位 相が淁とんぞ一致した場合（位相差 $0.1 \%$ 以内）飞行な われるよう考皇なければならない。もちろんパルス駆動, ブロッキング発振に上る水平偏向回路では上述の現象は 過渡応答が早いので問題とならない。

\section{VTR 出力信号との結合}

他局同期として VTR 出力信号を用いる場合が考学ら れる.これはスタジオ番組中に VTR 出力信号を插入す る場合で，番組の任意の時間にVTR を起動し，自動同 期結合装置でスタジオ同期を自動的に VTR に結合させ 映像信号の混合を可能にする方法である.この場合水平 同期を先にかけて，垂直を後にするか，またこの逆をと るかは重要な問題となる。すなわち VTR 出力信号に結 合した同期信号発生器の水平同期の位相は, VTR ヘッ ド切替光時の位相補償サーボの不完全性に追随して，画 面との相対位置が変化して曲りを生ずる.この曲りは静 止している場合には認知されないが, 先に水平をかけて, 垂直を後にする場合には上下に曲りが移動するので認知 される. 本装置ではこの影響を除くため，従来の方式と 逆に垂直を先にかけて, 後に水平結合を行なっている.

\section{4. 切替準備時間}

垂直位相差の検出から，水平同期の結合まで沉要する 準備時間は，(i) 垂直調相，最大 5 秒，平均 3 秒，（ii) 水平調相は $T=\frac{1}{\Delta f}(\mathrm{sec})$ である. 特飞水平調相は $\Delta f$ で決まるので自局水晶発振器を他局周波数より $1 \sim 2 \mathrm{c} / \mathrm{s}$ ぐらいずらして拉く方がよい，故に全ての動作が完了す るまでの時間は最大 6 秒程度の時間ずれを考兄ればよい。

\section{回 路 構 成}

前節の考慮を加味して構成された回路を第 5 図に示す この回路の個々の動作を第 1 図を参考にして説明する.

\section{1. 自局同期}

同期切替スイッチを $\mathrm{L}$ (自局同期) 飞すると $\mathrm{T}_{47}$ のト ランジスタは OFF となり,リレー\# 2 の接点は $\mathrm{L}$ 位置 炕ある。

(水平同期) $\mathrm{T}_{25}{ }^{\prime}$ 出力は, $\mathrm{T}_{8}, \mathrm{~T}_{9}$ 拈よび $\mathrm{T}_{11}, \mathrm{~T}_{12}$ の二個のフリップ・フロップの $\mathrm{T}_{8}, \mathrm{~T}_{11}$ をトリガし, 直結された $\mathrm{T}_{13}$ は $\mathrm{OFF}, \mathrm{T}_{10}$ は $\mathrm{ON}$ となり， $\mathrm{D}_{1}$ を導 通させる. 一方 $\mathrm{T}_{18}$ の $31.5 \mathrm{kc}$ 水晶発振器出力は $\mathrm{T}_{20}$ の $\div 2$ ブロッキング発振器を通して成形され， $\mathrm{T}_{21}$ を 通して $\mathrm{D}_{1}$ を経て $\mathrm{T}_{17}$ のエミッタ・コレクタから異極 性のパルスとして升別回路を駆動する．この弁別器には 自局同期信号発生器の水平駆動パルス (H. D)から発生し た比較信号としてののこぎり波が加わっているので，位

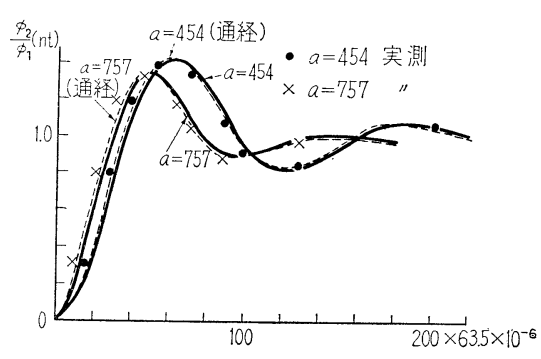

第 4 図 のこぎり波 $\mathrm{AFC}$ 回路の過渡応答

相差が検出され， $\mathrm{T}_{29}, \mathrm{~T}_{30}$ の $\mathrm{DC}$ 增幅器を経て, 同期 信号発生器は自局の $31.5 \mathrm{kc}$ 水晶発振器に結合する. こ こで $\mathrm{DC}$ 増幅器の $\mathrm{T}_{30}$ は $\mathrm{T}_{29}$ の温度变化による $I_{c 0}$ を 補正するものである. また $\mathrm{D}_{3}, \mathrm{D}_{4}$ は切替時の衝撃を防 止するためのるので, $\mathrm{DC}$ 出力電圧を制限し $0.2 \mathrm{~V}$ 以内 に収めている。

（垂直同期） $\mathrm{T}_{35}$ の入力が同期切替スイッチに連動し, L 位置にあるので，ベース入力は開放となって V. Lock 出力はない。

（映 像）同期切替スイッチがしにあるので， $\mathrm{T}_{28}$ の コレクタは $1 \mathrm{k} \Omega$ を通して $-18 \mathrm{~V}$ につな゙っているの で, リレー\#1の接点はL位置にあり, 映像は自局 $(\mathrm{L})$ だけしか取れない。

\section{2. 他局同期}

同期切替スイッチを $\mathrm{R}$ （他局同期）飞すると $\mathrm{T}_{47}$ の下 ランジスタは $\mathrm{ON}$ となり, リレー \#2 接点は L 位置で $\mathrm{T}_{47}$ のベース駆動信号で動作するようになる。

（垂直同期） $\mathrm{T}_{2}$ 上り $\mathrm{T}_{31}$ に加わった他局の複合同期は 積分回路を通って垂直成分のみとなり， $\mathrm{T}_{32}, \mathrm{~T}_{33}$ で成形 されて $\mathrm{T}_{34}, \mathrm{~T}_{34}{ }^{\prime}$ の Inhibit Gate に加わる. 一方, 自 局複合同期信号も， $\mathrm{T}_{39}$ から積分回路を通して $\mathrm{T}_{40}$ に 加わり, $\mathrm{T}_{41}, \mathrm{~T}_{42}$ の単安定マルチで幅を決めて Gate に 加わる. $\mathrm{T}_{34}$ のコレクタには両者の位相差があるときの みパルスを発生し，このパルスは位相補償パルスとして $\mathrm{T}_{35}$ に加わる. この場合同期切替スイッチは $\mathrm{R}$ 位置にあ るので， $\mathrm{T}_{36}$ のコレクタより正極性のパルスが，同期信 号発生器に加わり, 調相する. $\mathrm{T}_{34}$ のコレクタ出力パル スは, また $\mathrm{T}_{43}, \mathrm{~T}_{44}$ の単安定マルチを駆動し, その出 力は正極性パルスとして $T_{47}$ のベースに加わるので, $\mathrm{T}_{34}$ より位相差による補償パルスが出ている間, $\mathrm{T}_{47}$ は OFF 状態で, リレーは L 位置泉るる.自局と他局の位 相が一致すると， $\mathrm{T}_{47}$ の入力パルスがなくなるので $\mathrm{T}_{47}$ は $\mathrm{ON}$ となり,リレー\#2 の接点 $\mathrm{R}$ 位置となり, 水平同 期トリガ回線を切替觉，また垂直補償パルス回線を断と する.

（水平同期） $\mathrm{T}_{25}{ }^{\prime}$ の出力回線が $\mathrm{R}$ 位置にリレー\# 2 に 


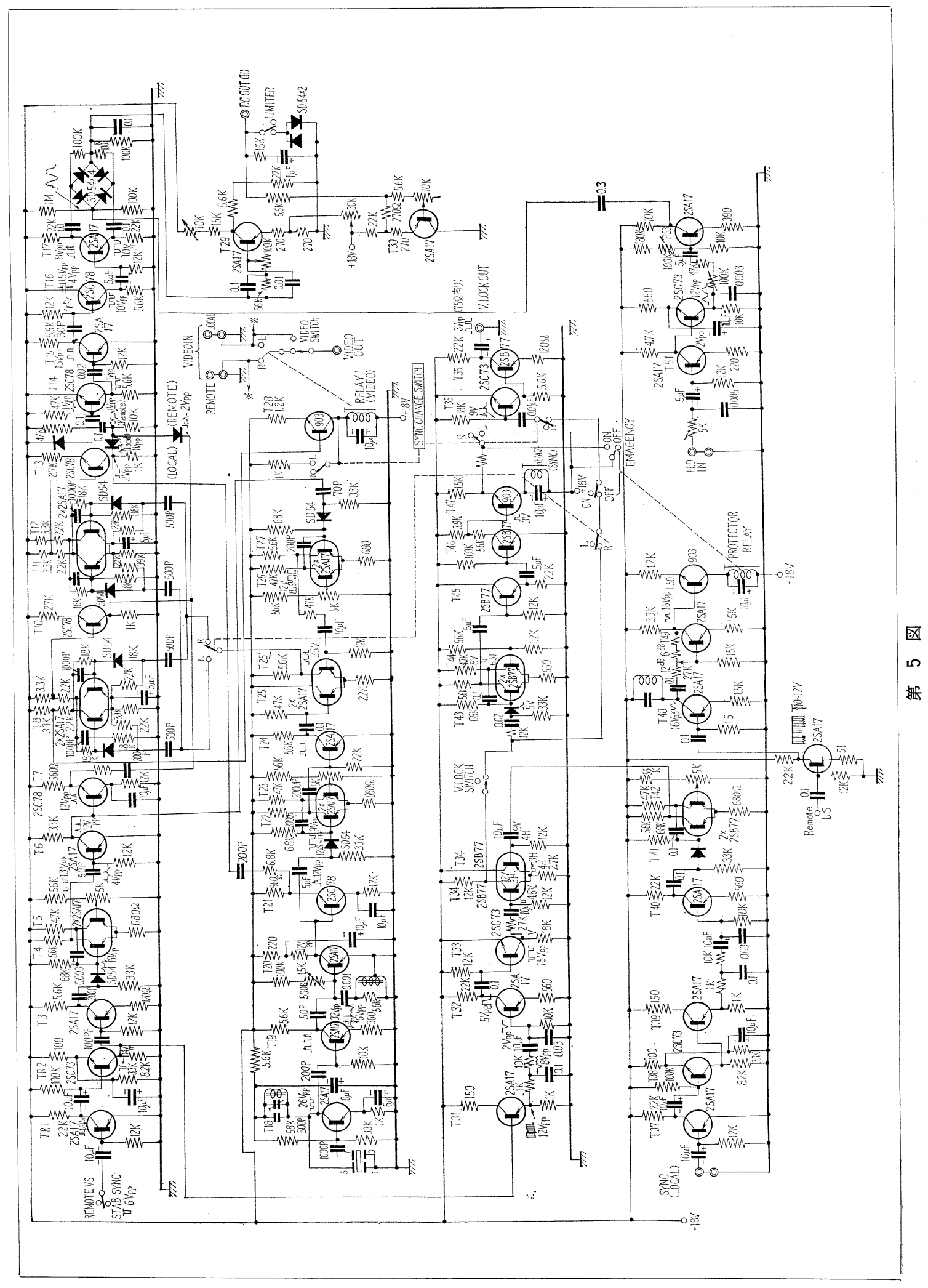




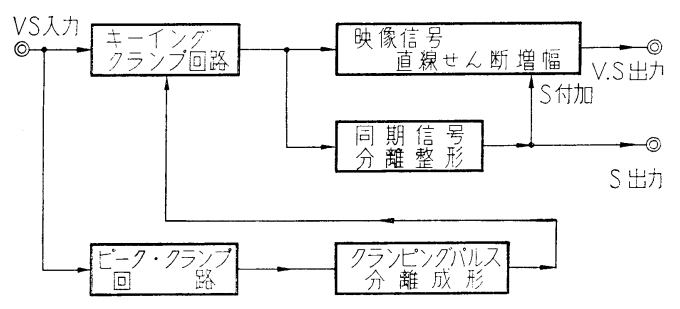

第 6 図 安定化増幅器回路方式

より,垂直調相後つながる. 一方, 他局の複合同期パルス は， $\mathrm{T}_{2}$ より $\mathrm{T}_{4}, \mathrm{~T}_{5}$ の単安定マルチに加わり， 15.75 kc のみのH成分になる. この単安定マルチはゲート作 用を持って括り， $\mathrm{H}$ パルスの期間のみゲートが閉じるよ うにしてまるので, 雑音に対して影響を受けることが少 なくない。この単安定マルチの出力は， $\mathrm{T}_{6}$ と $\mathrm{T}_{7}$ の出 力と二つにわかれ，前者は同期切替時間の設定をなし， 後者は $\mathrm{D}_{2}$ を通して $\mathrm{AFC}$ の弁別回路に加わる.すなお ち $\mathrm{T}_{6}$ の出力は $\mathrm{T}_{26}, \mathrm{~T}_{27}$ の単安定マルチで, 常に一定 なパルス幅となし AND GATE $T_{25}, T_{25}$ に加わる. このゲートは，自局と他局の位相が一致したとき（位相 差 $0.5 \%$ 以内に設定する.）のみ 単安定マルチの出力を トリガパルスとしてフリップ・フロップに加える.よっ て自局同期の場合と逆の側の $\mathrm{T}_{13}$ が $\mathrm{ON}, \mathrm{T}_{10}$ が $\mathrm{OFF}$ となり $\mathrm{D}_{2}$ が導通する.この結果, 弁別回路で他局同期
は自局同期信号発生器の $\mathrm{HD}$ と比較され, $\mathrm{AFC}$ は他局 に同期する.

（障害検出）以上の他局同期の動作は, $\mathrm{T}_{48}, \mathrm{~T}_{49}, \mathrm{~T}_{50}$, $\mathrm{T}_{54}$ の障害検出回路でチェックされ行なわれる.すなわ ち $T_{54}$ のベースに加わった他局 V.S. 信号は，増幅され て $\mathrm{T}_{48}$ の $15.75 \mathrm{kc}$ 同調増幅器に加わり, この増幅器出 力はプロテクターリレーを保持させる. ここで他局 V. $\mathrm{S}$ 信号が規定レベル（レベルは $6 \mathrm{~dB}, 9 \mathrm{~dB}, 12 \mathrm{~dB}$, の 三段階にプリセットできる.）以下になるとプロテクタ 一の保持が不能となり, 強制的にリレー接点が自局同期 に切替わる.これは，信号が規定值以上になれば，また 他局同期結合の過程が行なわれ他局同期に切替わる.

（映 像）完全に垂直同期の結合が終り，水平同期切 替のフリップ・フロップがトリガされ反転されたときに $\mathrm{T}_{8}$ のコレクタに直結した $\mathrm{T}_{28}$ が導通してリレーを $\mathrm{R}$ 位

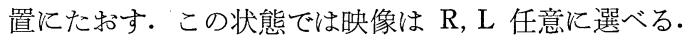

もちろん他局同期結合時に障害があって, 自局に同期 がかえれば映像も自局のみとなる。

\section{安定 化堌幅器}

他局映像同期信号は，伝送路でいろいろの雑音の混入 を受ける・これからできるだけ原信号に近い信号を取り 出すために, 安定化増幅器をこの自動同期結合装置内に 設けてある。

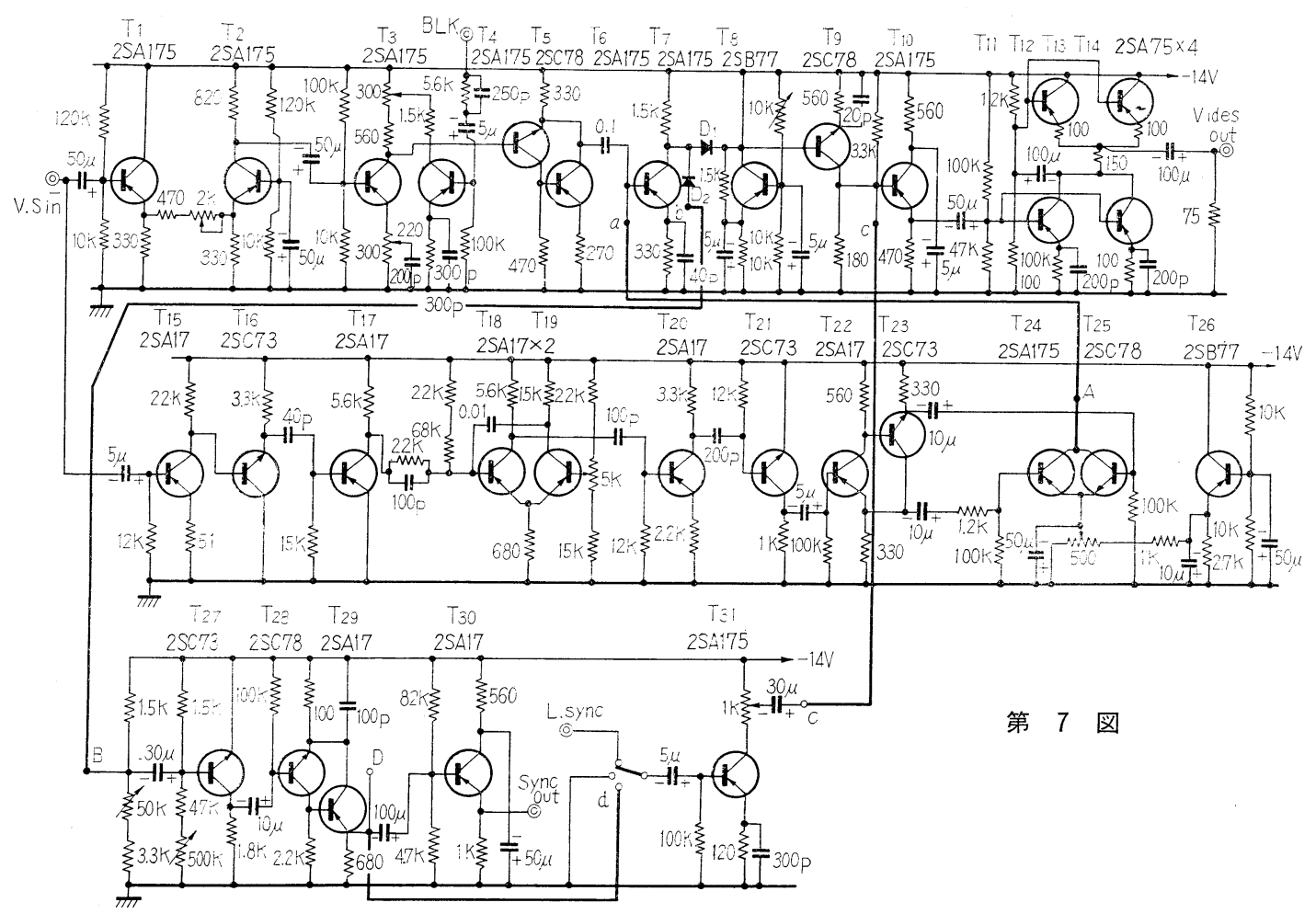




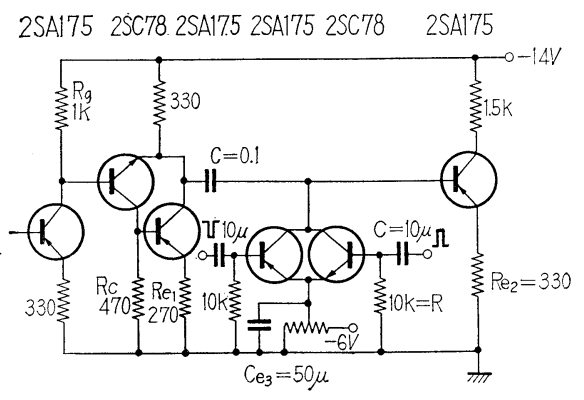

第 8 図クランプ 回 路

\section{1. 回路の方式および構成}

この安定化增幅器は, すでに NHK 技術研究所で真空 管式で試みられた第 6 図の方式注2)を用いている。この 方式は RCA 方式と異なり，キーイング・クランプ・パ ルスを分離するためのクランプ回路が別に設けられてい るので，ループを作らず各種雑音，特に衝撃性雑音に対 して安定度が高い.

第 7 図はこの増幅器の全回路図である.

$T_{1} T_{2}$ で利得調整し $T_{3} \sim T_{6}$ で帰線消去信号を付加し て被クランプ回路を低インピーダンスで駆動する.クラ ンプした後 $T_{7} D_{1} T_{8}$ で直線せん断して出力増幅部 $T_{9} \sim$ $\mathrm{T}_{14}$ から $75 \Omega$ 同軸ケーブルへ映像信号を送り出す. 一 方キーイング・パルスはVS 入力から直接同期分離成形 して $\left(\mathrm{T}_{15} \sim \mathrm{T}_{23}\right)$, クランプ回路 $\left(\mathrm{T}_{24} \sim \mathrm{T}_{26}\right)$ へ加光て いる. また同期信号の分離はクランプした後 $\mathrm{D}_{1}$ と同じ 点から $\mathrm{D}_{2}$ で行なって， $\mathrm{T}_{27}$ でスライスして出力回路 $\mathrm{T}_{28}$ $\sim \mathrm{T}_{30}$ から $4 \mathrm{Vp}-\mathrm{p}$ の同期信号を $75 \Omega$ 同軸ケーブルヘ 送り出す. 出力映像信号としてVS 信号が必要なとき化

注 2) NHK 技術研究 第10巻. 第 6 号 (33.11) 新型安定化增幅器とせ タップ付加回路（藤村，岩村）

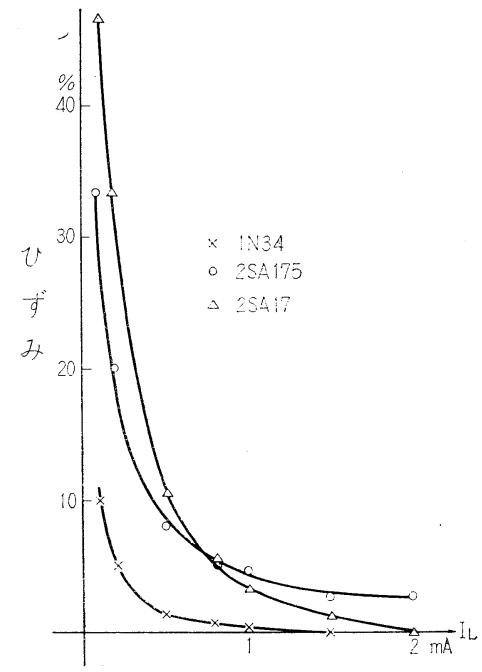

\section{第 9 図 \\ リニヤーク リッパーの非} 直線性
は， $\mathrm{T}_{31}$ から前記の整形された他局同期信号または同期 結合された自局同期信号のいずれかを選んで $T_{10}$ へ加完 られる.これらの回路で特に問題となった部分について 説明する.

\section{2. クランプ回路}

トランジスタの低い飽和抵抗を利用して，バックポー チのレベルを固定するもので，考光方は真空管の場合と ほぼ同じである、クランプ能率を良くするためには，ク ランプ回路への前段出力インピーダンスが低く, 被クラ ンプ回路の入カインピーダンスが高いことが望ましい. またクランプ回路の導通時のインピーダンスと非導通時 のインピーダンス比も大きくする必要がある. 第 8 図に おいて前段出力インピーダンス $z_{0}$ は

$$
\begin{aligned}
& z_{0} \doteqdot \frac{R_{g} / h_{f e}+r_{d}}{1+R_{c} / R_{e 1}} \\
& h_{f e}: \quad \text { エミッタ接地電流增幅率 } \\
& r_{d}: \quad \text { エミッタ拡散抵抗 } \\
& 1+R_{c} / R_{e 1}: \text { フイードバックペアの帰還量 }
\end{aligned}
$$

で表わされ約 $15 \Omega$ である.

また被クランプ回路の入カインピーダンスは，エミッ 夕接地を使った場合,

$$
\begin{gathered}
z_{i n}=r_{b^{\prime}}+\left(r_{d}+R_{e 2}\right)\left(1+h_{f e}\right) \fallingdotseq R_{e 2} \cdot h_{f e} \\
r_{b}{ }^{\prime}: \text { ベースひろがり抵抗 }
\end{gathered}
$$

となり，図に打ける定数では $h_{f e}$ が 140 以上のトラン ジスタを選べば， $z_{i n}$ は $50 \mathrm{k} \Omega$ 以上となる。このときの 水平周期のサグを $1 \%$ 以下にするには，結合コンデンサ $C_{c}$ は

$$
\begin{aligned}
& C_{c} \geqq \frac{1}{f_{h} \cdot z_{i n} \cdot \delta}=\frac{1}{15.75 \times 50 \times \frac{1}{100}}(\mu \mathrm{F}) \\
& \delta: \text { サグ }
\end{aligned}
$$

の関係から $0.1 \mu \mathrm{F}$ 以上が必要となる.

実際の回路に叔いて， $\mathrm{T}_{24}, \mathrm{~T}_{25}$ のベースの $\mathrm{CR}$ 時定 数も問題となる.すなわちべースの時定数が大きずる と，ベース電流が減少して飽和抵抗は大きくなる. 反対 に小さすぎると非導通時にベース側のパル大電圧とコレ クタ側の映像信号の相対関係からコレクタ接合が筯通し て映像信号がクリップされるので，より大きな入力パル スが必要となる. 実験によれば, 時定数は $0.5 \sim 0.1$ 秒に 選ぶのが適当で, このときの飽和抵抗は $5 \Omega$ 程度となる。

以上の回路に杼いて，キーイング・クランプ・パルス の幅を $3 \mu \mathrm{sec}$ にすると $36 \mathrm{~dB}, 2 \mu \mathrm{sec}$ にすると 33.5 $\mathrm{dB}$ のハム改善率が得られる.な招 $\mathrm{T}_{24} \mathrm{~T}_{25}$ のエミッタ にある $C_{e 3}$ は結合コンデンサ $C_{c}$ に比して，十分大きく しなければならない。

\section{3. 直線せん断回路}

映像同期信号から映像信号だけをとり出す場合，その 


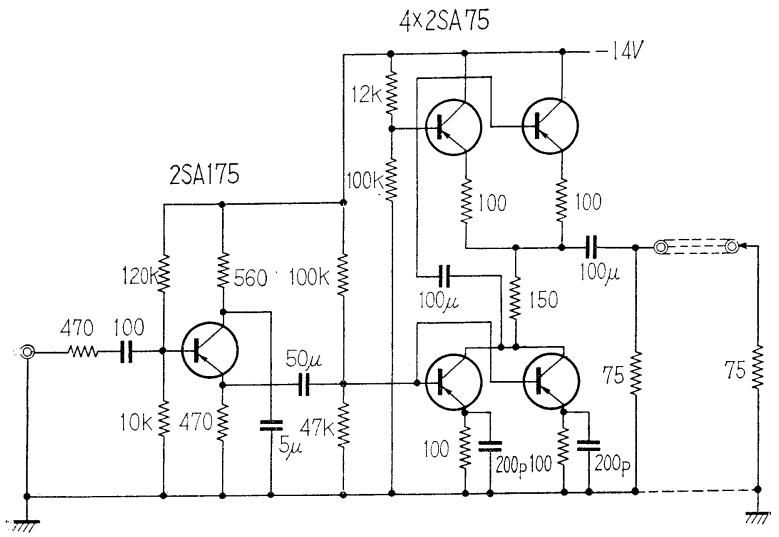

直線性が問題となる.一般にダイオードが用いられるが， ダイオードの直線部の彎曲によって映像信号の黒レベル 側が縮まる傾向がある. 実験によるとダイオード電流が $0.5 \mathrm{~mA}$ では $1 \%, 1 \mathrm{~mA}$ では $0.3 \%$ のひずみを生じ た.な拈トランジスタのベース・エミッタ接合を使った 場合， $1 \mathrm{~mA}$ 流しても 3〜4\%のひずみとなり実用にな らない。第 9 図はその実験結果である.

\section{4. 映像出力回路}

線路インピーダンス $75 \Omega$ にS $1.4 \mathrm{Vp}-\mathrm{p}$ を送り出 すための回路で，一般にエミッタホロワを用いてインピ 一ダンスを整合している，しかし，その場合直流分の阻 止が実際上困難であるため，いろいろの障害の原因とな っている.

ここではコレクタ結合型シャントレギュレーテッド増 幅器を使って出力インピーダンスを上げ, 結合コンデン サによって直流を阻止している.この出力回路は高イン ピーダンス型なのでインピーダンス整合のため $75 \Omega$ 抵 抗をケーブル送端に插入する必要がある.よって出力回 路からみた負荷インピーダンスは $37.5 \Omega$ になるので ${ }^{-} \mathrm{T}_{11} \sim \mathrm{T}_{14}$ の 4 本のトランジスタを使った第10図(a) の ような回路にする. 各トランジスタのバイアスは $V_{C E}$ $=-4 \mathrm{~V}, \quad I_{e}=10 \sim 13 \mathrm{~mA}$ である. この回路のドライブ にはエミッタホロワを使用している.ドライバーを含め た出力回路の周波数特性を同図( $b$ ) に示す.

\section{5. 同期分離回路}

キーイング・クランプ・パルスの分離には, 同期結合

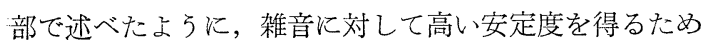
単安定マルチを用いている. 送り出し用の同期信号の分 離については，ダイオード $\mathrm{D}_{2}$ によって分離するだけで なく, トランジスタ $\mathrm{T}_{27}$ でもスライスする.つまり $\mathrm{D}_{2}$ によって, 同期信号の基部を切り，トランジスタ $\mathrm{T}_{27}$ の バイアスによって頭部を切る.こうすることにより雑音 の混入した同期信号の中間部（雑音は基部と頭部に重睤

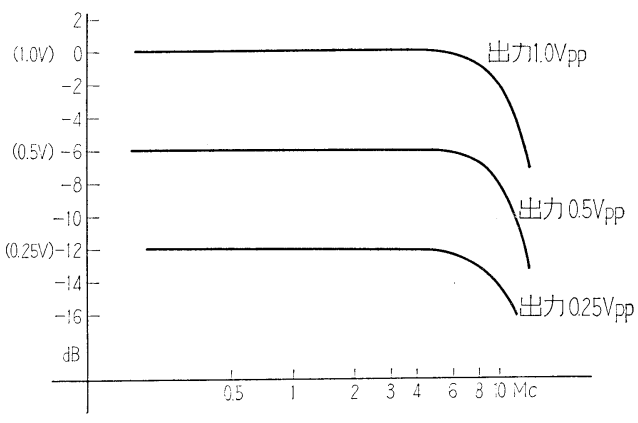

第 10 図 (b) 映像出力回路周波数特性 (a) 映像出力回路 (shunt regulated amp.)
されている）のみをとって整形した雑音のない同期信号 が得られる．しかしこの動作中に位相が遅れるので，映 像信号との相対位相を保つため映像回路に遅延ケーブル を入れる・それと同時に同期位相特よびパルス幅を調整 する必要がある。

\section{6. 性 能}

以上の各回路を検討してこの安定化増幅器は次のよう な性能を持っている.

（1）規定出力を得るための最小入力信号レベル

（2）最大出力レベル（正弦波）

$0.4 \mathrm{Vp}-\mathrm{p}$

(3) 八厶改善度

$3.5 \mathrm{Vp}-\mathrm{p}$

(4) 直線せん断ひずみ $30 \mathrm{~dB}$

(5) クランプパルスの混入 $0.3 \%$

（6）入力信号変動に対する安定度（最小VS 信号） $-16 \mathrm{~dB}$

（7）遅延ケーブルによる補償時間

$0.4 \mu \mathrm{sec}$

\section{むす び}

以上自動同期結合装置について, 安定増幅器を含めて 説明したが，本器は実際にヘリコープから到来する電波 について自動結合を試み, またビデオテープレコーダ出 力との結合に执いても優れた結果を示した.この他，多 元中継を行なう場合でも A 局結合から B 局結合の切替え を一台の同期信号発生器で, 一度自局同期にして行なえ ば可能で，聴取者には一連の番組として同期結合を認知 し得ない. 今後, 局内設備が自動化するにしたがって, このような結合装置の優用が要求されるであろう.

終りに，この研究の機会を与えられ，助言を戴いた三 ホテレビ研究部長, 石橋副部長, 樋渡主任研究員, また 種々の実際的なデータを取られ，いろいろ討議された技 術現業局テレビ操縦課下津課長, 山岸職員に感謝する. 